\title{
THE COMING OUT OF MEMORY The Holocaust, Homosexuality, and Dealing with the Past
}

\author{
Arnaud Kurze \\ Montclair State University \\ kurzea@montclair.edu
}

\begin{abstract}
This research discusses the challenges of establishing a collective memory for gay victims of the Nazi terror in World War II and examines the introduction of gay victimhood into the public sphere through memorialization efforts. While scholarly accounts on gays and the Holocaust emerged in the 1970s, little is known about the emergence and consolidation of a public narrative on gay persecutions under the Nazis. It raises important questions, including why a public voice for crimes against sexual minorities in World War II emerged only hesitantly? Drawing on historical gay memorialization processes in Germany, the author maps the obstacles for recognition, including external and internal challenges in expanding existing narratives and a collective memory of the past. This fraught advocacy work remains nonetheless crucial to promote commemorations of persecution and discrimination against minority groups that have received limited public acknowledgement.
\end{abstract}

\section{Keywords}

collective memory; Nazi crimes; gay and lesbian; transitional justice; memorials

\section{About the Author}

Arnaud Kurze is Assistant Professor of Justice Studies at Montclair State University. His research focuses on transitional justice studies, social movements, and human rights. Dr. Kurze was appointed a Global Fellow at the Woodrow Wilson Center in Washington, DC, from 20162020, studying youth resilience in North Africa and the Middle East. He has published widely in academic journals, contributed to edited volumes, and is author of several reports on foreign affairs for government and international organizations. He is the co-editor of New Critical Spaces in Transitional Justice: Gender, Art \& Memory. 


\section{INTRODUCTION}

In recent years, advocates of lesbian, gay, bisexual, and transgender (LGBT) rights have found international support, particularly with the United Nations Human Rights Council's (UNHRC) passage of a resolution to acknowledge these rights globally. ${ }^{1}$ The extent to which governments grant these minority rights and protect individuals from abuses, however, still varies greatly across regions and countries (Weiss and Bosia; Picq and Thiel). In addition, current human rights struggles to fight for equality and protection are overshadowed by a burdensome past of persecutions, including in particular the repression of sexual minorities during the Nazi regime. Yet, it took decades before the German government officially recognized these crimes, and the creation of a historical dialogue to acknowledge these victims was marred by contentious politics. In my research I map the challenges of establishing a collective memory for gay victims, i.e. male homosexual victims (admittedly different, but related to the LGBT rights movement more broadly), of the Nazi terror in World War II and examine the introduction of gay victimhood into the public sphere through memorialization efforts.

Accounts on gays and the Holocaust ${ }^{2}$ emerged in the 1970s, predominantly retracing the history and individual narratives of the victimization during this period (Hammermeister 18-26; Heger; Schult). This literature sought to capture and narrate the stories of gay Nazi victims using a personalized historical writing style that served a cathartic and revelatory purpose especially for those who survived the atrocities. ${ }^{3}$ Although some of the works could be categorized as memory studies in a broad sense, little is known about the emergence and consolidation of a public narrative on gay persecutions under the Nazis. The formation of such a collective memory is important as a point of departure for a public dialogue about the past for gay victims. The term collective memory used in this article is based on a dynamic, multi-layered concept that draws from early research on memory studies spearheaded by Emile Durkheim, Maurice Halbwachs, and Pierre Nora. In fact, "collective memories change according to the needs and concerns of each generation" (Adamczyk cited in Jordan 38). The formation, appropriation, and change of identity-driven memory processes are therefore at the heart of this research. While gender issues have drawn scholarly attention to issues of women's rights and sexual violence during conflict especially in recent years (Aoláin, Haynes, and Cahn; Branche and Virgili; Inal), academic literature on dealing with the past on male homosexuality issues remains limited. Certain works in the past few years have addressed questions with respect to contemporary conflicts and grappling with the issue of overcoming taboos in the process of recognizing these crimes when dealing with human rights violations and mass atrocities (Carpenter; Christian et al.; Dolan). Some of the current, persisting challenges fuel questions about the historical conditions of victims of sexual crimes during conflict. It 
raises the question, for instance, as to why a public voice for crimes against sexual minorities in World War II emerged only hesitantly? What obstacles did gay Nazi victims have to face when seeking recognition for crimes committed during the Third Reich? Drawing on historical gay memorialization processes in Germany, I map the sociopolitical challenges that gay activists were confronted with when dealing with the past. I argue that claiming and consolidating identity-based memorialization processes via public spaces also creates tension between existing victim claims and emerging narratives of victimhood. Yet, this fraught advocacy work remains nonetheless crucial to drawing attention to commemorations of persecution and discrimination against minority groups that have received limited public acknowledgement.

In the following, I trace the emergence of a gay Holocaust body of literature and analyze its role within the field of memory and transitional justice studies. The second part of my article explores the relationship between homosexual identity in society and the challenging emergence of gay Nazi victimhood post-1945. Drawing on memorialization processes in Germany during the 1990s, I then map the creation of several gay memorials to commemorate the persecution of male homosexuals during the Holocaust. By comparing spatial and contextual differences, I discuss the roles of space and victimhood in memory politics associated with each of the memorials.

\section{TRANSITIONAL JUSTICE, GAY ACTIVISM, AND REMEMBERING THE PAST}

In this section, I discuss the role of sexual minority rights advocacy in transitional justice studies and, in particular, the tensions and challenges associated with the historical trajectory of commemorative practices and memorials. To this end, I first turn to the concept of memory. The science of memory is a large field, including a variety of perspectives and disciplines, such as neuroscience, behavioral science, and social science. In recent years, researchers have attempted to integrate and bridge some of the scholarly approaches (Roediger, Dudai, and Fitzpatrick). One of the fathers of the sociologically-oriented approach to memory studies, Maurice Halbwachs, posited that collective memory "depends on the social environment" (37). Hence, the construction of shared narratives remembered by groups of individuals is affected and often shaped by those who create the story. "This is especially the case when the event is of a nature that arouses deep emotions in groups of people, giving rise to passionate discussions," he notes (194). Identityshaping practices therefore come at a cost, and it suffices to look at the processes of remembering and forgetting. The former, however, cannot be fully understood without embracing the concept of the latter-an active process deemed necessary

Kritika Kultura 33/34 (2019/2020): 763-785

(C) Ateneo de Manila University

<http://journals.ateneo.edu/ojs/kk/> 
to human survival by Nietzschean standards and cursed by Sigmund Freud and his disciples in the field of psychoanalysis because it buries human trauma in a person's subconsciousness (Casey 8). In terms of collective memory and society, this means that the issue lies in certain social groups possibly being actively forgotten, i.e. excluded, from an emerging historical narrative, which then creates a potential for conflict. ${ }^{4}$ In turn, the potential conflict is a latent, socially constructed, and structural form of violence, which impedes the peaceful resolution of conflict. The conundrum nonetheless does not reside in the lack of non-violent measures, but in the structure of our legal system and concept of justice. According to Walter Benjamin, a nonviolent conflict resolution results in "possible violence" as the involved parties preserve "the right to take recourse to violence in some form against the other, should he break the agreement" (288). Increasingly, scholarship has condemned social injustice and structural inequality as a result of globally expanding Westernized legal and institutional frameworks, particularly embracing a critique of twenty-first century, UN-driven (and/or other powerful actors) perspectives of dealing with the past (Fourlas; Madlingozi; Di Lellio and McCurn). As a case in point, Rosemary Nagy argues that "predominant views construct human rights violations fairly narrowly to the exclusion of structural and genderbased violence" (276). Despite a growing debate on gender and race in the field, the path to a more inclusive interpretation of the past is filled with obstacles. ${ }^{5}$

Second, drawing on collective narratives from the Holocaust, I analyze the difficulties of a historical narrative that was inclusive of World War II minority victims, particularly of sexual minorities. The Shoah, the mass murder of Jews under the Nazi regime during World War II, has fueled extensive debates that still continue today. The ever-expanding corpus of scholarly work and literature on the Shoah, along with the development of the field of Holocaust studies itself, is notable in its sharp contrast to the more limited scope of works that focused on non-Jewish victims of the Third Reich, such as homosexuals and Roma, ${ }^{6}$ that also emerged in the postwar period. Hans Neumann's 1972 memoir of Josef Kohut, a gay victim of the Nazi terror (written under the pen name Heinz Heger), inspired Martin Sherman's controversial play, Bent, which came out in 1979 (Buckley). It was also the catalyst for the emergence of a handful of individual narratives in subsequent decades (Heger). These personal accounts eventually led to the development of academic scholarship on the topic. Compared to the significant portion of Holocaust literature that relied on victim-centered narratives, the literature that was written after the public disclosure of Nazi crimes against homosexuals, particularly in the 1980 os and 1990s, materialized in a different context. As the topic remained a taboo for many years in society-anti-gay laws remained in place, such as the notorious Paragraph 175 in Germany, which criminalized sodomy and which was only revoked completely after the German reunification in 1994 (Reuters) - capturing the story of gay Nazi victims presented a different and difficult challenge and, with the death of the last 
known gay victim a few years ago (Weinthal), individual narratives remain limited to the few already published accounts.

Although some research has addressed the question of a gay Nazi memory (Jensen), few are the studies that engage with broader questions pertaining to transitional justice issues. Transitional justice generally refers to measures implemented by transition governments to address past grave human rights violations or mass atrocities during times of political violence or autocratic repression. Measures include human rights trials, truth commissions, amnesties, and memorials among others. For this research, I focus mainly on memory-related practices. As an established scholarly field, memory studies has also consolidated its foothold in the more recent field of transitional justice studies (González-Enríquez and Aguilar). Yet, research that explores violence against the gay community and questions on how to account for these crimes and generate a collective memory is less developed. While a keyword search on "sexual violence" in the archival flagship publication of the field, The International Journal of Transitional Justice, results in 131 articles, the issues addressed are mainly associated with female rape and the question of reparations. A separate search on "gay," "lesbian," or "homosexual," on the contrary, shows only a total of 13 different articles related to the topic (Campbell; Cole; Chappell, Grey, and Waller; Dimitrijevic; Hamber; Powell; Rubio-Marín and de Greiff; Vijeyarasa; Wilke; de Waardt; Bueno-Hansen; Lemay Langlois; Rooney and Aoláin). ${ }^{7}$ Among this limited selection of articles, however, topics range widely with the main focus on accountability and reparations without a direct link to the gay community. Christiane Wilke's work constitutes the exception, as it discusses identity questions and commemorative processes drawing on the Memorial to the Homosexuals Persecuted under the National Socialist Regime in Berlin and comparing it to the Herbert Baum Group memorial, which honors the Jewish victims of the Holocaust. Her work is compelling, pointing to the complexity of victims and she urges transitional justice studies to consciously embrace this issue, despite obvious difficulties:

Transitional justice as a practice and field of inquiry stands to gain much from an engagement with intersectionality theories. These theories will help to recognize that state violence often involves the persecution of people with different and intersecting identity markers. [...] There is a temptation to ignore or downplay the complexity and fluidity of identities. For the sake of justice and memory, it is imperative to recognize the complexities of identities past and present and to remember that identities are always works in progress. (139)

While she goes into great detail of how complex identities, including political affiliation and sexuality, became points of contention during Germany's public debate of a collective memory of the Holocaust in postwar society, her focus 
remains limited to a theoretical discussion of memory formation (141-152). More importantly, she does not venture into tracing the genesis of a gay collective memory to commemorate the homophobic persecutions during the national socialist regime. Below, I will therefore pave the way for a broader debate on gay Nazi crimes, collective memory, and the relationship of space and memorials in a German context.

\section{HOMOSEXUAL IDENTITY IN SOCIETY, VICTIMHOOD AND MEMORY POLITICS}

Activists promoting rights for sexual minorities have a long history of advocating for equal rights. Strategies and activities to reach their advocacy goals within society have changed over time. A fleeting, historical topography of the conceptual transformation helps contextualize the challenges of gays in post-World War II to gain recognition for injustices during the Nazi era. In the enlightenment era, for instance, English writer Thomas Cannon published works in defense of homosexuality, creating an early deliberative space for a taboo topic in society. Parts of his writing are preserved through texts about the indictment of his printer John Purser, who was sentenced for publishing immoral obscenities (Gladfelder). Pushing the agenda a little further, the first known intellectual to argue for the decriminalization of homosexuality was utilitarian philosopher, Jeremy Bentham. Yet, his text was not published until 1978. According to English laws in the late 1700 homosexuality was punishable by hanging (Bentham and Crompton, “Offences Against One's Self: Paederesty [Part 1]"; Bentham and Crompton, "Jeremy Bentham's Essay on 'Paederesty' [Part 2]"). In spite of these gay rights pioneers, England was not the only place homosexuality flourished in the post-Renaissance period. France, Spain, and Italy were also known for an emerging subculture (Gerard and Hekma; Rey; Berco; Rocke). These early developments are merely a sketch of some of the major tropes that emerged over the span of several centuries and serve to highlight the importance of incremental changes pushed for by members of the community by creating and relying on specific frames-a collection of narratives or stories, that people use to understand and respond to events- to promote their cause (Goffman). ${ }^{9}$ In this context, Michel Foucault's 1976 History of Sexuality sharply captured the creation and evolution of a gay identity, discussing the conceptual transformation from medicalization of homosexuality, including pederasty, bestiality, and sodomy, to erotic and sexual same-sex attraction. ${ }^{10}$

The cradle of modern gay rights advocacy gained momentum in the second half of the nineteenth century, long before Foucault's influential work was published. Ironically, it occurred in Germany, within the context of Paragraph 175, that was passed under the newly created Reich in 1871 (Beachy 803-804). ${ }^{11}$ In the prewar 
period, a scientific discourse promoted by Magnus Hirschfeld emerged, stressing that homosexuality was a "third sex," a congenital condition and therefore should not be punishable under German law (62). Hirschfeld's organization, the Scientific Humanitarian Committee, attempted to educate society on the rights for gays advocating for "justice through science" (547). ${ }^{12}$ Other groups, such as the Gemeinschaft der Eigenen, under the leadership of Adolf Brand, a school teacher and publisher of the first homosexual periodical Der Eigene, nurtured a discourse of personal liberation to improve the social image of male intimacy and bonding in light of a classicist cult of youthfulness and beauty (Roper). The group's body cult and obsession with aesthetics, unfortunately, did not help their fate during the rise of the Nazi regime and during World War II. Many homosexuals were arrested, sent to concentration camps, and often succumbed to the cruel treatment by the Nazis under Hitler's reign. Lesbians, while also targeted, were not as harshly exposed and did not succumb to the same cruel treatments as their male counterparts. Under the laws of the Third Reich, Paragraph 175 did not extend to women. In other words, the legal question of criminalizing lesbian activities did not result in adding female same-sex practices to the penal code in 1934, as "women are always prepared for sex" (Grau and Shoppmann 10). The differentiation between gender-specific practices was based on fertility and to what extent a particular behavior would endanger the procreational and political agenda of the Nazi regime. In addition, Hitler's regime excluded women from power positions in the Reich, which eliminated any perception of lesbian women as being a danger for society or for the political ambitions of the Nazi establishment (8).

Also, while many sexual minorities were deprived of civil rights under Nazi rule, male homosexuals particularly suffered under the regime. This discrimination inevitably led to different perceptions and narratives of the past by sexual minorities and regime victims due to the differences in lived experiences that were hence at the origin of misunderstandings, social tensions, and identity-related issues between various victim groups. Homosexuals in postwar Germany struggled to redress the past since the infamous Paragraph 175, the law that made homosexuality a crime under the Nazi regime, remained on the books under the new democratic government in West Germany in the 1950s (Epstein and Friedman). It was not until after the reunification of Germany that public authorities acknowledged the suffering and persecution of homosexuals, erecting memorials and performing commemorative practices. These practices, however, also illustrate the difficult process of creating a collective memory to tell a narrative of past injustice to present and future generations, which, in addition, is marred in a spatial struggle for recognition. 


\section{MEMORIALIZATION PROCESSES IN GERMANY AND GAY MEMORYSCAPES}

The erection of monuments for commemorative purposes fosters identity-driven memorialization and puts physical spaces center stage. "The metaphorical force of the notion of locality is also a product of the structure of feeling referred to as 'belonging, itself a defining attribute of personal and collective identity" (Nuttal, "Building a Nation" 223). Mark Nuttall referred to the close-knit relationship between identity, memory, and locality as "memoryscapes" (Nuttall, Arctic Homeland 39). These "lieux de mémoire" or memory spaces are "mixed, hybrid, mutant, bound intimately with life and death, with time and eternity, enveloped in a Möbius strip of the collective and the individual, the sacred and the profane, the immutable and the mobile" (Nora cited in Hirsch 22). The juxtaposition of symbolic identity-laden layers of meaning in a confined physical space inevitably creates tensions between the goals of remembering and forgetting. While the latter is generally associated with helping the victims overcome trauma, the former aims at establishing practices that foster a memory culture in the hope of deterring future atrocities (Jelin). It is nonetheless an intricate process filled with obstacles, illustrated by the struggles of activists in Argentina during the transition period in the 1990s. "At the individual level, one can only forget what one has lived through. This is not what the human rights movement is after; rather, it is a collective memory and the fear of collective forgetting" (Jelin 49). Attempts by homosexual activists to claim public spaces of remembrance to chastise and commemorate Nazi crimes also faced delicate challenges, primarily because they occurred during a historical era of tectonic sociopolitical shifts, including the global AIDS crisis, ${ }^{13}$ the collapse of the Soviet Union, and the reunification of Germany. This historical backdrop weighs heavily, as James Young points out with regards to German commemorative practices: "no other nation has ever attempted to re-unite itself on the bedrock memory of its crimes or to make commemoration of its crimes the topographical center of gravity in its capital" (cited in Jordan 59). The reunification process, which was characterized by a challenging transformative experience for both East and West German societies, has therefore "revolved primarily around questions of how to anchor Holocaust commemoration in the national historical consciousness of a unified Germany and how to choose forms of cultural memory that best suit this end in the "nation of the guilty"' (Hoffmann cited in Jordan 6o). While collective memory debates in post-Berlin Wall Germany were driven by an official narrative, the memorialization of the 1990 os was not a unidirectional process. Instead it was a contested and complicated back and forth in which grassroots movements played an influential role (Jordan 38).

Given the context of the gay liberation movement and the illegality of homosexuality in postwar Germany, public acknowledgement of the persecution of homosexuals under the Nazi regime occurred tardily and unfolded in several

Kritika Kultura 33/34 (2019/2020): 768-785

(C) Ateneo de Manila University

<http://journals.ateneo.edu/ojs/kk/> 
stages. In a groundbreaking speech at the occasion of the 4oth anniversary of the end of World War II, German President Richard von Weizäcker addressed the West-German Bundestag (parliament) in 1985, emphasizing the beginning of a new era, which would officially commemorate gay victims of the Holocaust in Germany (Jensen 336). ${ }^{14}$ Despite this highly symbolic gesture, Bavarian gay and lesbian associations advocating for the installation of a pink triangular plaque at the concentration camp in Dachau initially faced opposition from victims groups in charge of overseeing the memorial site (Oloew). The reluctance by established victims groups to spatial claims by a newly recognized category of World War II victims is grounded in identity-related fears. Existing victims associations felt that the collective memory of Holocaust survivors was questioned by a new narrative. The memoryscape of Dachau's concentration camp was also associated with a deeply rooted Catholic, Bavarian society, which left little room for rights of sexual minorities. Moreover, these protests happened at the height of the gay and lesbian rights campaigns in Germany in a heavily charged political climate. As a case in point, Bavarian interior minister Peter Gauweiler proposed a repressive anti-AIDS policy, which suggested locking up HIV-infected individuals to contain the spreading of the disease (Stroh). While today's collective memories have been "increasingly leaking or breaking out of the 'container of the nation-state' due to the formation of a global arena," authorities in the 1980 os were able to disseminate public narratives based on a powerful nation-state paradigm (Assmann 547). As a result, victims of sexual crimes during the Nazi terror had to wait for almost another decade before larger memorials were also erected outside already existing memorial sites.

While competing narratives of victimhood may fuel or deepen existing conflict, Michael Rothberg's "multidirectional model" based on the "recognition of the productive interplay of disparate acts of remembrance" constitutes a refreshing alternative, particularly for contexts that require partial or full reinterpretation of established collective memory tropes (309). The erection of memorials to honor gay Nazi victims in Germany required a paradigmatic shift of the existing public narrative, which excluded the suffering of homosexuals under Hitler's reign. The new narrative needed to be based on a broader historical understanding of the Third Reich era. This goal was reflected in the architecture and the symbolism that different gay memorials portrayed to the German public. In the following, I delve further into questions of space, belonging, and memory formation, paying particular attention to symbolic meanings of sculptured monuments as well as the location choice for their erection. The history of the creation of various monuments commemorating gay Nazi victims across Germany epitomizes the challenging memorialization process and gay rights activism over the last few decades. The process of publicly commemorating and including the sufferings of this victim group eventually culminated in a national debate at the German parliament in the 
capital, leading to the erection of the Memorial to Homosexuals Persecuted under Nazism in Berlin in 2008. ${ }^{15}$

The first, notable German monument was erected in 1994 in Frankfurt, a commemorative figure in the form of an angel. ${ }^{16}$ The so-called Frankfurt Angel, designed by contemporary artist Rosemarie Trockel, ${ }^{17}$ symbolically captures and contextualizes the struggle of gay victims for recognition within society. As the artist explains:

The quasi classical form of a circle divided by a cross contradicts the shape of the square, which is an obliquely distorted, irregular rectangle. The relationship between the circle and irregular rectangle resembles thus the juxtaposing link of the angel's dislocated head and clipped wings in relation to the Gothic Revival of the 19th century, a product of which it is. ${ }^{18}$

The atypical and contradictory constellation of geometric forms and the powerful image of an androgynous angelic symbol reflect the hostile conditions to which gay men and women were exposed in a predominantly heteronormative environment. Although they were part of the social tissue, their otherness and uniqueness rendered them vulnerable in times of persecution and criminalization of homosexuality. The monument also blurs the lines between what Dominick LaCapra distinguishes as "structural" and "historical trauma" in society (699). The latter is event-based; in other words, the suffering and mourning relate to a particular historical injustice inflicted on a victim group. The former, on the contrary, is an injustice that is embedded in social norms and practices that span over larger periods of time and might transgress spatial boundaries as well. Slavery or socio-economic exploitations of minorities serve as excellent examples. Needless to say, the social stigma of homosexuals transgressed the immediate post-1945 period. Hence, the monument's advocates also assured that the socio-cultural differences be embedded into an adequate geographic space and design. It is situated on the Klaus Mann Square, in downtown Frankfurt, close to the epicenter of the city's gay scene and subculture. Four stone benches are placed around the monument, encircled by a boxwood hedge to provide peace and quiet in the midst of a hectic and busy urban setting. The chosen location by advocates accentuates nonetheless underlying consequences of identity-driven collective memory processes. On the one hand, the spatial reference to Frankfurt's gay scene and subculture solidifies a community-centered zeitgeist that aims at local empowerment through collective memory processes. Memory here has the power to reinforce the identity of a group by reconstructing a particular notion of the past, thus unifying individuals who are part of the collective (Assmann and Czaplicka 130). On the other hand, the spatial fixation and geographic boundaries pose a dilemma for the purposes of memory formation and generating a shared memory culture that aims at reaching beyond 
socio-cultural fault lines. Post-Cold War German society, with its various migrant cultures, serves as a case in point, as the question of how migrant populations react to the historical memory of their host country continues to fuel public debates in Germany (Huyssen, "Diaspora and Nation" 154). ${ }^{19}$

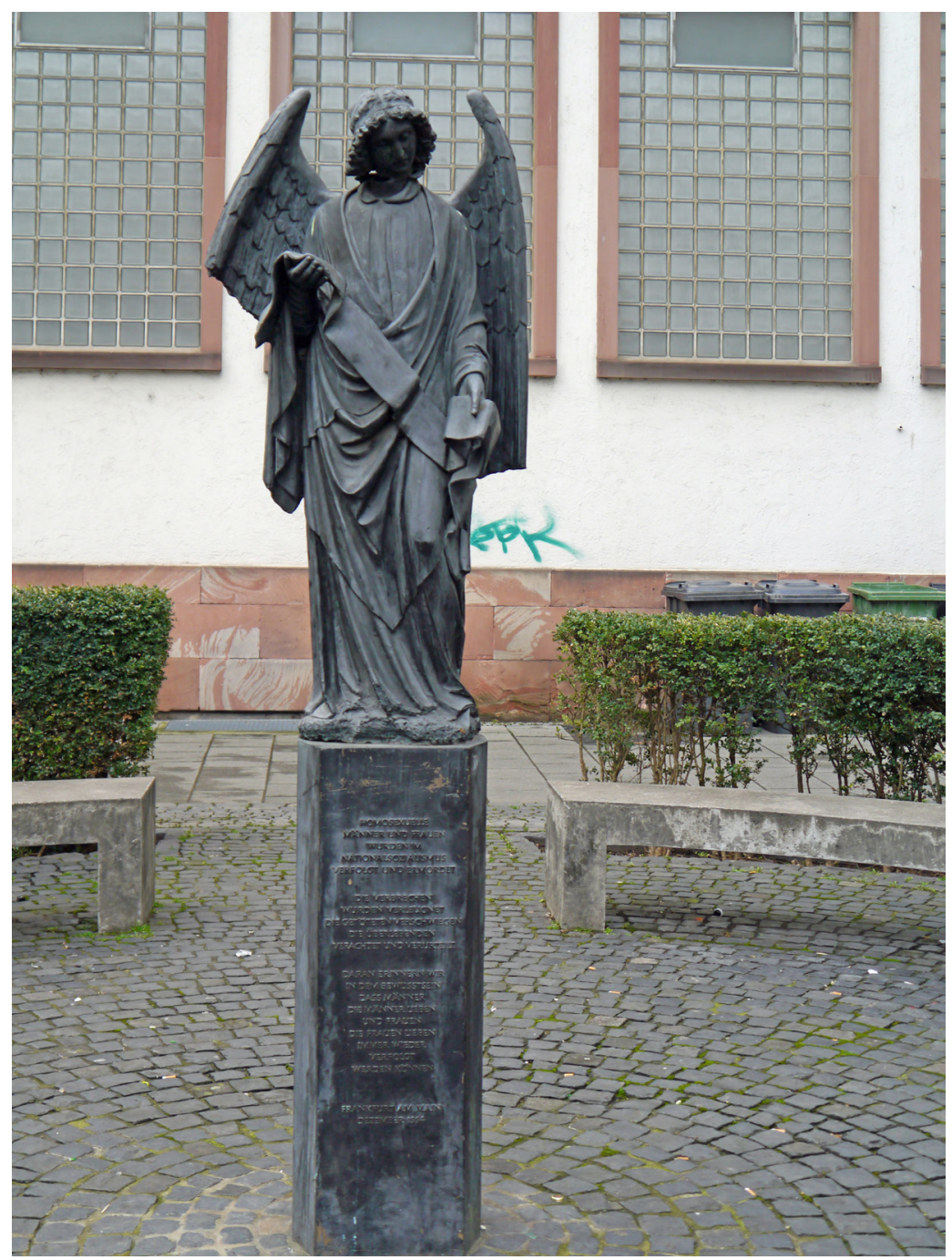

Fig. 1. Frankfurt Angel on Klaus Mann Square. Photo credit: Reinhard Dietrich.

The introduction of abstraction and symbolism in memorials can be seen as a means to create a larger, unifying message. Both of these artistic approaches were part of a trend that characterized post-1945 Holocaust memorialization practices (Marcuse). Cologne's memorial for the gay and lesbian victims of National Socialism 
showcases the artistic endeavor of rendering abstract and metaphorical symbolism in a sculpture. The memorial is shaped in the form of two granite blocks, one of which was in the shape of a pink triangle and was built in 1995 along the Rhine River. The sculpture includes a quote "Hushed - Killed," words that had already become the message of choice on several commemorative plaques installed in several concentration camps. ${ }^{20}$ It was created by sculptor Achim Zinkman and consists of two differently colored granite blocks that form a whole. As described by its creator, "A gray, a pink block. Parts of a society. Men women. lesbian, gay, mutually oppressive, rubbing against each other, entangled and protected, impacting one another." ${ }^{21}$ With the pink triangle penetrating the second granite block, geometric forms are also at the heart of the artist's preoccupation to create a work that provokes a feeling of tension and unease among visitors. It is an effort to create a "prosthetic memory," an experience that does "not erase differences or construct a common origin," as Allison Landsberg argues (9). "People who acquire these memories are led to feel a connection to the past, but all the while, to remember their position in the contemporary moment," she notes (9). In addition, the monument displays the heterogeneous composition of society and draws attention to the conflictual nature of the relationship between different socio-cultural groups. The monument location was also chosen based on its historical importance to gay culture, in an effort to transcend the confinement of temporal boundaries. While Cologne is the center of German contemporary gay culture, the Hohenzollern Bridge was a historical meeting point for gays during the early twentieth century and after 1945 . The site choice for the memorial could be interpreted as an attempt to achieve the ambitious objective of "critical reconstruction," i.e. creating socio-cultural meaning to a once important area that is retrieved from oblivion (Ladd 12).

To further extrapolate the issue of space and symbolic meaning for identitybuilding narratives, I turn to Berlin's efforts to memorialize gay Nazi victims, particularly with the inauguration of the Memorial to Homosexuals Persecuted under Nazism, commonly known as the Gay Memorial, in 2008. Suffice to say that Berlin was an important gay mecca during the Belle Epoque and the interwar period, Berlin provided refuge to many artists and sexual minorities trying to escape the conservative mores of the Wilhelmine era (Tamagne). The gay memorial site itself, located in the Tiergarten, carries symbolic value not only as a meeting point for gays in the first half of the twentieth century, but also because Magnus Hirschfeld's Institut für Sexualwissenschaften, a private sexology research institute, was situated in the borough of Berlin-Charlottenburg in close proximity to the Tiergarten. This memorial, however, occupies an essential turning point in gay memorialization culture. Paradoxically, gay memorialization practices in Germany followed a counter-cyclical pattern. While many collective memory efforts sought authenticity in non-traditional sites and local communities (Jordan 38), the German post-reunification era highlights the importance of Berlin as a central space for the 


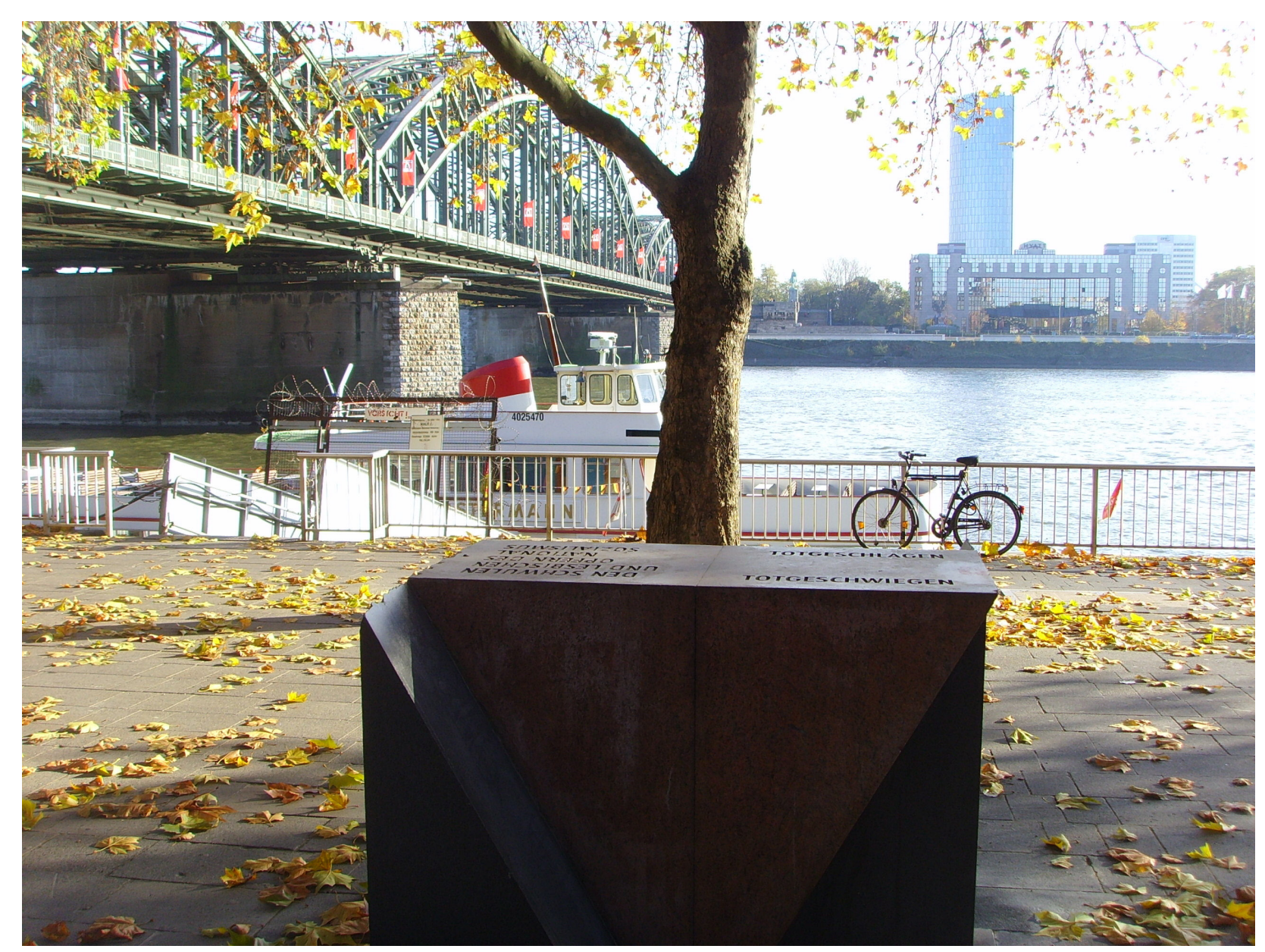

Fig. 2. Cologne Memorial to Gay and Lesbian Victims of National Socialism.

Photo credit: Jörg Lenk.

creation and dissemination of nation-wide social memory tropes. German political elites were at the center of heated public debates. As Jennifer Jordan highlights, "[s] tates make landscapes, but this does not mean that they are uniformly making memory" (39). In the case of German gay Nazi victims, the strength of local activist groups advocating across the country raised awareness to their cause at the national level, illustrating the importance of grassroots and civil society in shaping public narratives of the past. "A society's memory is negotiated in the social body's beliefs and values, rituals and institutions ... it is shaped by such public sites of memory, such as the museum, the memorial, the monument" (Huyssen, "Monument and Memory" 249). While public spaces are still primarily defined by national politics and political institutions, such as the German Bundestag, deliberation strategies by alternative social actors have increasingly affected official narratives of the past and 


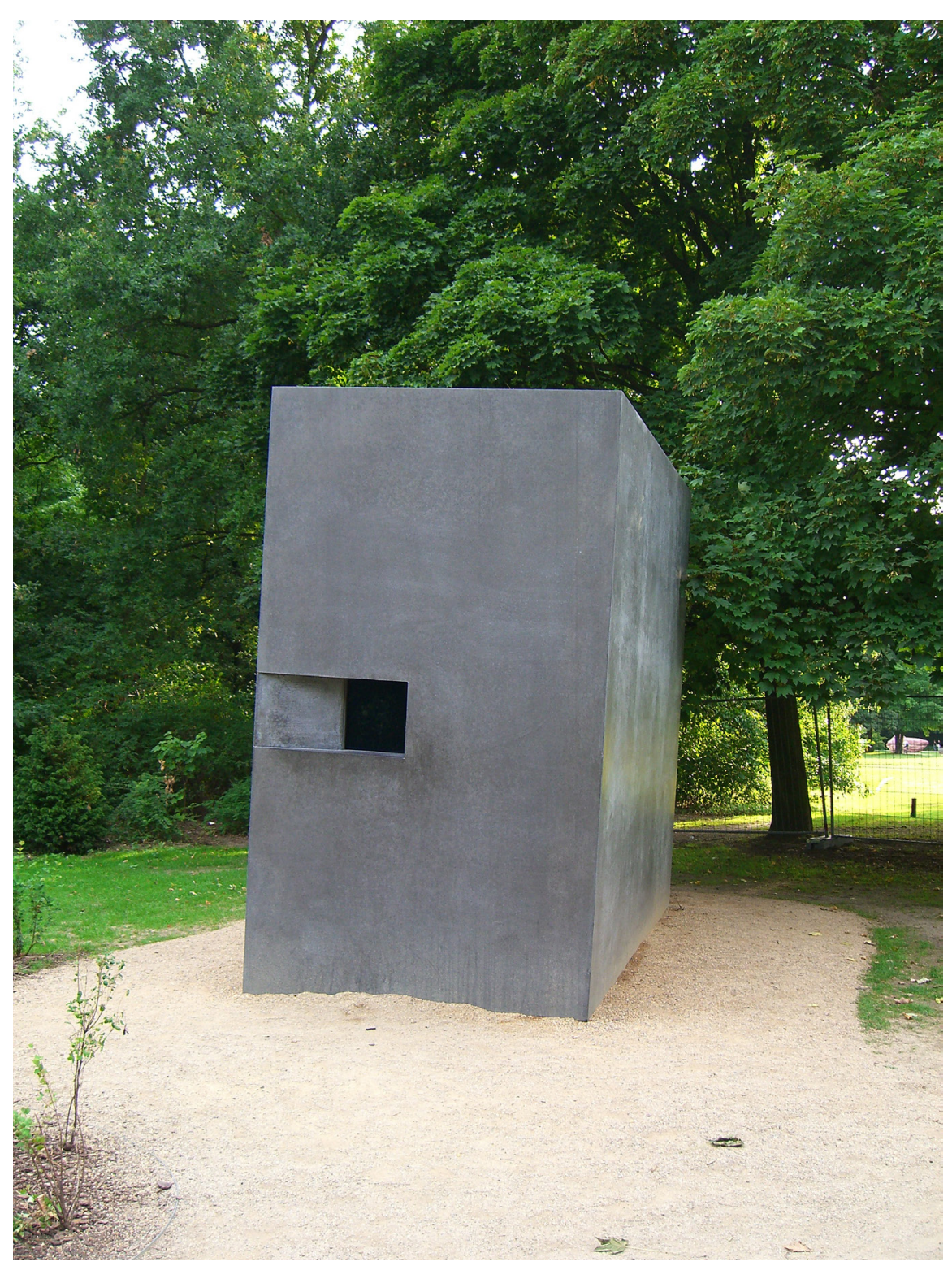

Fig. 3. Memorial to Homosexuals Persecuted Under Nazism in Berlin. Photo credit: Times.

in the case of gay Nazi victims, generated a recognition of their victimhood after decades of being sidelined and marginalized by society.

In terms of memorialization projects, the Berlin memorial was the third work of its kind, after Frankfurt and Cologne, and its architectural design represents a continuation of the symbolism conceptualized by the previous memorial sites. ${ }^{22}$ 
The cuboidal monument is made of concrete and includes a window on its front side. By looking into the window, which is diagonally cut into a corner of the cube, the viewer can watch a film of alternating same-sex couples kissing. The film's original projection was a seemingly endless kissing scene of a male same-sex couple installed for a two-year period. ${ }^{23}$ The purposely tilted concrete block symbolizes the queer lifestyle of the marginalized, so called Querdenker, referring to individuals who think outside the heteronormative framework. The tilt thus stands in direct opposition to the orderly organized social structures of society. In addition, the small opening at one of the corners of the concrete block forces visitors to approach the monument and engage with the inert object, voyeuristically discovering the message inside the dark and ominous installation. The memorial was nonetheless plagued by a series of politicized issues, including a debate on whether or not to include lesbian footage for the film and a heated discussion whether a separate commemorative site in addition to the Holocaust Memorial was necessary and appropriate (Standard; Welle). The inclusion of interactively engaging art inside the monumental sculpture, however, bears witness to the trust in art to face the Holocaust and creates a more effective confrontation of space and memory (Ladd 15). Art thus serves as an additional medium to foster a narrative for long-time marginalized victims that might also facilitate broader deliberation within German society and beyond.

\section{CONCLUSION}

In closing, it is worthwhile to note that memorialization has also occurred beyond Germany's borders. The Netherlands, for instance, spearheaded this trend with the construction of the Homomonument in Amsterdam as early as $1987 .{ }^{24}$ More recently, Israeli LGBT activists pushed for the installation of a pink triangle in Gan Meir Park in Tel Aviv in 2013, joining other cities including Frankfurt, San Francisco and Sydney in their efforts to remember the past (Aderet). Larger LGBT advocacy efforts, however, have also been politicized by state actors. In the case of Israel, for instance, critics have condemned the government's effort to paint a rosy picture of supporting gay rights, while at the same time committing human rights violations in the occupied territories. This phenomenon is called "pinkwashing" and has been further discussed and referred to as homonationalism (Schulman; Puar). The long and bumpy road to recognition for gay Nazi victims is, however, not an exception. There are many cases that parallel this historical evolution with minorities still struggling in the midst of politics of memory to find adequate acknowledgement and commemoration of their victimhood. 
In this article, I examined the politics of memory drawing on homosexual identity and the persecution of gays during the Holocaust from a transitional justice perspective. The primary focus centered on the questions of why the "coming out" to acknowledge the wrongdoings took so long and why gay activists harnessed the emerging homosexual victim accounts about the Nazi terror to promote gay victimhood in Western societies. First, I mapped the emergence of a gay Holocaust body of literature and discussed its role within the field of transitional justice studies. Then I analyzed the link between homosexual identity in society and gay Nazi victimhood in post-1945 Germany. Drawing on social movements campaigning during the 1990 os for more visibility and recognition of gay victims of the Nazi regime in Germany, I examined the erection of several gay memorials to honor gay Nazi victims in postwar German society. A discussion on Germany's post-reunification memorialization of gay victims further underlined the tension between space, identity, and memory. Based on practices of remembrance fostered by the gay activists, I also found that unifying calls for acknowledging past injustice may trigger underlying contentious politics within the competing victim communities, which may lead to a politicization of the past. "Since public memory is produced in a particular political context it is vulnerable to political change" (Light and Young 235). The findings of this study should serve as a catalyst for future research that sheds light on the politically motivated silencing of victimhood narratives, particularly of minority groups. Nonetheless, it demonstrates the importance of facing the challenge to unearth and contest politicized narratives through scholarship and advocacy despite the intricate difficulties of addressing the underlying issues and overcome perpetuated injustices. 


\section{Acknowledgements}

This article was developed from an idea in a paper presented at the annual meeting of the American Society of Criminology from 16-19 November 2015 in Washington, DC. I wish to thank Christopher Lamont, Tokyo International University; Vjeran Pavlakovic, University of Rijeka; and Mietek Boduszynski, Pomona College; for their insightful comments and suggestions that helped improve my initial draft. I would also like to thank my assistant Claudia Meraviglia at the Woodrow Wilson Center for her diligent archival work and research assistance. In addition, I am grateful to Allison Sherrier, the two anonymous reviewers, and the editors of this journal for reading earlier drafts of this article and providing valuable comments to help clarify certain aspects. I am also indebted to Marcos Zunino, Gabriel Rubin, and many other colleagues and friends for the many conversations that helped strengthen this article.

\section{Funding and Grant-Awarding Bodies}

This work was supported by the Woodrow Wilson International Center for Scholars. Grant number: 80-6-0028. 


\section{Notes}

1. United Nations Human Rights Council, 27th session. Human Rights, Sexual Orientation and Gender Identity (No. A/HRC/RES/17/19), 2011, http://undocs. org/en/A/HRC/RES/17/17. Accessed 11 Jun. 2018. See also the 2014 follow-up resolution by the United Nations Human Rights Council, Human Rights, sexual orientation and gender identity (No. A/HRC/RES/27/32), 2014, http://undocs.org/ en/A/HRC/RES/27/32. Accessed 11 Jun. 2018.

2. "Holocaust" in this study refers to the crimes committed by Nazis against all types of victims while the term "Shoah" specifically refers to the atrocities committed against Jewish victims.

3. See for instance Gobodo-Madikizela and Van Der Merwe; Radford; and Kearney.

4. Several cases across different regions illustrate this problem today. These include tensions between South Korea and Japan vis-à-vis comfort women during World War II; the present revisionism of Peruvian political elites of the Fujimori era; Rwanda's problematic, state-controlled narrative about the genocide; and the challenging rapprochement of ex-Yugoslav countries after the violent breakup in the 1990 s hampered by unaddressed historical World War II memories.

5. For an excellent study on male African-American identity and sexism, see Curry. On more general race-related issues, see Mills. For a detailed discussion on gender, see Pateman.

6. For an account on breaking the silence surrounding Roma persecutions during the Holocaust, see for instance Stojka.

7. The search was performed 28 Jan. 2018.

8. For a detailed discussion on this topic, see Gerard and Hekma, part IV.

9. For a discussion on frames in social movement theory, see for instance Benford and Snow.

10. The third and last volume was published in 1984 in French, the English version in 1986.

11. For a detailed historical account of the rise of the prewar modern gay movement in Germany, see for instance Steakley.

12. This slogan, in Latin "Per scientiam ad justitiam," was the motto of Hirschfeld's Scientific Humanitarian Committee.

13. The AIDS epidemic has been referred to as the gay holocaust, see for instance Mass.

14. The first commemoration with an official plaque was held in the Austrian concentration camp in Mauthausen in 1984.

15. It was inaugurated by the openly gay left-wing mayor of Berlin, Klaus Wowereit.

16. A gay rights advocacy group called "Initiative Mahnmal Homosexuellenverfolgung e.V." created in Frankfurt in 1990 was instrumental in the creation of a memory space for the gay victims of national socialism.

17. Trockel's work is part of the collection of the Museum of Modern Art in New York.

Kritika Kultura 33/34 (2019/2020): 778-785

(C) Ateneo de Manila University

<http://journals.ateneo.edu/ojs/kk/> 
18. See the monument's official website, http://www.frankfurter-engel.de/home.html. Accessed 3 Dec. 2017.

19. See also the debate in German Parliament on how to teach the Holocaust to Muslims in Germany (Smale).

20. The German words read "Totgeschlagen - Totgeschwiegen."

21. Description given by the artist and translated by the author. For more details see the monument's website, http://www.rosa-winkel-mahnmal.de/gestaltung. Accessed 3 Jan. 2018.

22. The monument was designed by the Danish-Norwegian artist duo Michael Elmgreen and Ingar Dragset.

23. Other films have been used since the inauguration, including kissing female samesex couples.

24. For more details about the monument, seeitswebsite, http://www.homomonument. nl. Accessed 3 Nov. 2017. 


\section{Works Cited}

Aderet, Ofer. "Memorial to Gay Holocaust Victims Inaugurated in Tel Aviv Park - National." Haaretz, 11 Dec. 2013, https://www.haaretz.com/gay-shoah-victims-memorialin-ta-1.5298605. Accessed 13 Feb. 2019.

Aoláin, Fionnuala Ní, Dina Francesca Haynes, and Naomi Cahn. On the Frontlines: Gender and the Forms and Experiences of Conflict. Oxford UP, 2011.

Arendt, Hannah. Eichmann in Jerusalem: A Report on the Banality of Evil. The Viking Press, 1963.

Assmann, Aleida. “Transnational Memories." European Review, vol. 22, no. 4, 2014, pp. $546-56$.

Assmann, Jan, and John Czaplicka. "Collective Memory and Cultural Identity." New German Critique, NGC, no. 65, 1995, pp. 125-33.

Beachy, Robert. "The German Invention of Homosexuality." The Journal of Modern History, vol. 82, no. 4, 2010, pp. 801-38.

Benford, Robert, and David Snow. "Framing Processes and Social Movements: An Overview and Assessment." Annual Review of Sociology, 2000, pp. 611-39.

Benjamin, Walter. Reflections: Essays, Aphorisms, Autobiographical Writings, edited by Peter Demetz, First Edition, Schocken, 1986.

Bentham, Jeremy, and Louis Crompton. "Jeremy Bentham's Essay on 'Paederesty' (Part 2)." Journal of Homosexuality, vol. 4, no. 1, 1978, pp. 91-107.

--. "Offences Against One's Self: Paederesty (Part 1)." Journal of Homosexuality, vol. 3, no. 4, 1978, pp. 389-406.

Berco, Cristian. Sexual Hierarchies, Public Status: Men, Sodomy, and Society in Spain's Golden Age. U of Toronto P, 2007.

Branche, Raphaëlle, and Fabrice Virgili. Rape in Wartime. Palgrave Macmillan, 2012.

Buckley, Tom. "Bent' to Dramatize Little-told Nazi Horror; A Youngster during the War." The New York Times, 15 Nov. 1979, pp. C17.

Bueno-Hansen, Pascha. "The Emerging LGBTI Rights Challenge to Transitional Justice in Latin America." The International Journal of Transitional Justice, vol. 12, no. 1, 2018, pp. 126-145. DOI:10.1093/ijtj/ijxo31.

Campbell, Kirsten. "The Gender of Transitional Justice: Law, Sexual Violence and the International Criminal Tribunal for the Former Yugoslavia." The International Journal of Transitional Justice, vol. 1, no. 3, 2007, pp. 411-32.

Carpenter, R. Charli. "Recognizing Gender-Based Violence against Civilian Men and Boys in Conflict Situations." Security Dialogue, vol. 37, no. 1, 2006, pp. 83-103.

Casey, Edward S. Remembering, Second Edition: A Phenomenological Study. Indiana UP, 2009.

Chappell, Louise, Rosemary Grey, and Emily Waller. "The Gender Justice Shadow of Complementarity: Lessons from the International Criminal Court's Preliminary Examinations in Guinea and Colombia." The International Journal of Transitional Justice, vol. 7, no. 3, 2013, pp. 455-75. 
Chare, Nicholas, and Dominic Williams. Representing Auschwitz: At the Margins of Testimony. Palgrave Macmillan, 2013.

Christian, Mervyn, Octave Safari, Paul Ramazani, Gilbert Burnham, and Nancy Glass. "Sexual and Gender Based Violence against Men in the Democratic Republic of Congo: Effects on Survivors, Their Families and the Community." Medicine, Conflict, and Survival, vol. 27, no. 4, 2011, pp. 227-46.

Cole, Elizabeth A. "Transitional Justice and the Reform of History Education." The International Journal of Transitional Justice, vol. 1, no. 1, 2007, pp. 115-37.

Curry, Tommy J. The Man-Not: Race, Class, Genre, and the Dilemmas of Black Manhood. First edition, Temple UP, 2017.

Dekel, Irit. Mediation at the Holocaust Memorial in Berlin. Palgrave Macmillan, 2013. de Waardt, Mijke. "Naming and Shaming Victims: The Semantics of Victimhood." The International Journal of Transitional Justice, vol. 10, no. 3, 2016, pp. 432-50.

Dimitrijevic, Nenad. "Serbia After the Criminal Past: What Went Wrong and What Should Be Done." The International Journal of Transitional Justice, vol. 2, no. 1, 2008, pp. 5-22.

Di Lellio, Anna, and Caitlin McCurn. "Engineering Grassroots Transitional Justice in the Balkans the Case of Kosovo." Eastern European Politics and Societies: EEPS, vol. 27, no. 1, 2013, pp. 129-48.

Dolan, Chris. Into the Mainstream: Addressing Sexual Violence against Men and Boys in Conflict. Overseas Development Institute, 2014.

Epstein, Rob, and Jeffrey Friedman. Paragraph 175. Telling Pictures, 2000.

Finkelstein, Norman G. The Holocaust Industry: Reflections on the Exploitation of Jewish Suffering. Verso, 2000.

Fourlas, George N. "No Future without Transition: A Critique of Liberal Peace." The International Journal of Transitional Justice, vol. 9, no. 1, 2015, pp. 109-26.

Friedman, Jonathan C. The Routledge History of the Holocaust. Routledge, 2010.

Gerard, Kent, and Gert Hekma. The Pursuit of Sodomy: Male Homosexuality in Renaissance and Enlightenment Europe. First edition, Routledge, 1989.

Giles, Geoffrey J. “'The Most Unkindest Cut of All': Castration, Homosexuality and Nazi Justice." Journal of Contemporary History, vol. 27, no. 1, 1992, pp. 41-61.

Gladfelder, Hal. “The Indictment of John Purser, Containing Thomas Cannon's Ancient and Modern Pederasty Investigated and Exemplify'd." Eighteenth-Century Life, vol. 31, no. 1, 2007, pp. 39-61.

Gobodo-Madikizela, Pumla, and Chris Van Der Merwe. Memory, Narrative and Forgiveness: Perspectives on the Unfinished Journeys of the Past. Cambridge Scholars Publishing, 2009.

Goffman, Erving. Frame Analysis: An Essay on the Organization of Experience. Harper Colophon, 1974.

González-Enríquez, Carmen, and Paloma Aguilar. The Politics of Memory: Transitional Justice in Democratizing Societies. Oxford UP, 2001.

Grau, Günter, and Claudia Shoppmann. The Hidden Holocaust? Gay and Lesbian Persecution in Germany 1933-45. Routledge, 2013. 
Halbwachs, Maurice. On Collective Memory. Translated by Lewis A. Coser, First edition, U of Chicago P, 1992.

Hamber, Brandon. "Masculinity and Transitional Justice: An Exploratory Essay." The International Journal of Transitional Justice, vol. 1, no. 3, 2007, pp. 375-90.

Hammermeister, Kai. "Inventing History: Toward a Gay Holocaust Literature." German Quarterly, vol. 70, no. 1, 1997, pp. 18-26.

Hass, Aaron. In the Shadow of the Holocaust: The Second Generation. Cambridge UP, 1996.

Hayes, Peter, and John K. Roth. The Oxford Handbook of Holocaust Studies. Oxford UP, 2010 .

Heger, Heinz. Die Männer Mit Dem Rosa Winkel. Der Bericht Eines Homosexuellen über Seine KZ-Haft von 1939-1945. Merlin Verlag, 1972.

Hirschfeld, Magnus. The Homosexuality of Men and Women. Prometheus Books, 2000.

Hirsch, Marianne. "Mourning Postmemory." Graphic Subjects: Critical Essays on Autobiography and Graphic Novels, edited by Michael Chaney, U of Wisconsin P, 2011, pp. 17-44.

“Homosexuellen-Denkmal: ‘Emma' Kritisiert Vergessene Frauen.” Der Standard, 29 Aug. 2006, https://derstandard.at/2563766/Homosexuellen-Denkmal-Emma-kritisiertvergessene-Frauen. Accessed 13 Feb. 2019.

Huyssen, Andreas. "Diaspora and Nation: Migration into Other Pasts." New German Critique, NGC, no. 88, 2003, pp. 147-64.

--. "Monument and Memory in a Postmodern Age." The Yale Journal of Criticism, vol. 6, no. 2, 1993, p. 249.

Inal, Tuba. Looting and Rape in Wartime Law and Change in International Relations. U of Pennsylvania P, 2013.

Jelin, Elizabeth. "The Politics of Memory: The Human Rights Movements and the Construction of Democracy in Argentina." Latin American Perspectives, vol. 21, no. 2, 1994, pp. 38-58.

Jensen, Erik N. "The Pink Triangle and Political Consciousness: Gays, Lesbians, and the Memory of Nazi Persecution." Journal of the History of Sexuality, vol. 11, no. 1, 2002, pp. $319-49$.

Jordan, Jennifer A. "A Matter of Time: Examining Collective Memory in Historical Perspective in Postwar Berlin." Journal of Historical Sociology, vol. 18, no. 1-2, 2005, pp. $37-71$.

Kampinski, Marian. Remember Me: A Holocaust Survivor's Story. iUniverse, 2009.

Karpf, Anne. "Chain of Testimony: The Researcher as Surrogate Witness." Representing Auschwitz: At the Margins of Testimony, edited by Nicholas Chare and Dominic Williams, Palgrave Macmillan, 2013, pp. 85-104.

Kearney, Richard. "Narrating Pain: The Power of Catharsis." Paragraph, vol. 30, no. 1, 2007, pp. 51-66.

LaCapra, Dominick. “Trauma, Absence, Loss." Critical Inquiry, vol. 25, no. 4, 1999, pp. 696-727. 
Ladd, Brian. "Center and Periphery in the New Berlin: Architecture, Public Art, and the Search for Identity." PAJ: A Journal of Performance and Art, vol. 22, no. 2, 20oo, pp. $7-21$.

Landsberg, Alison. Prosthetic Memory: The Transformation of American Remembrance in the Age of Mass Culture. Columbia UP, 2004.

Lautmann, R. "The Pink Triangle. The Persecution of Homosexual Males in Concentration Camps in Nazi Germany." Journal of Homosexuality, vol. 6, no. 1-2, 1980, pp. 141-6o.

Lemay Langlois, Léa. "Gender Perspective in UN Framework for Peace Processes and Transitional Justice: The Need for a Clearer and More Inclusive Notion of Gender." The International Journal of Transitional Justice, vol. 12, no. 1, 2018, pp. 146-167. DOI:10.1093/ijtj/ijxo34.

Light, Duncan, and Craig Young. "Public Memory, Commemoration and Transitional Justice: Reconfiguring the Past in Public Space." Post-Communist Transitional Justice: Lessons from Twenty-five Years of Experience, edited by Lavinia Stan and Nadya Nedelsky, Cambridge UP, 2015, pp. 233-51.

Madlingozi, Tshepo. "On Transitional Justice Entrepreneurs and the Production of Victims." Journal of Human Rights Practice, vol. 2, no. 2, 2010, pp. 208-28.

Marcuse, Harold. "Holocaust Memorials: The Emergence of a Genre - UCSB Department." American Historical Review, vol. 115, 2010, pp. 53-89.

Mass, Lawrence. "AIDS and the Holocaust." The New York Times, 23 Oct. 1988, https:// www.nytimes.com/1988/10/23/books/l-aids-and-the-holocaust-156488.html. Accessed 13 Feb. 2019.

Mills, Charles. "White Ignorance." Race and Race and Epistemologies Epistemologies of Ignorance of Ignorance, edited by Shannon Sullivan and Nancy Tuana, State U of New York P, 2007, pp. 13-38.

Nagy, Rosemary. “Transitional Justice as Global Project: Critical Reflections." Third World Quarterly, vol. 29, no. 2, 2008, pp. 275-89.

Nuttall, Mark. Arctic Homeland: Kinship, Community, and Development in Northwest Greenland. U of Toronto P, 1992.

-.. "Building a Nation Today: People and Places in Greenland." Heritage and Identity: Shaping the Nations of the North, edited by J. M. Fladmark and Thor Heyerdahl, Routledge, 2015, pp. 223-38.

Oloew, Von Matthias. "Ecce Homo." Der Tagesspiegel, 24 Maz 2008, https://www.pnn.de/ kultur/ueberregional/von-matthias-oloew-ecce-homo/22439058.html. Accessed 13 Feb. 2019.

Pateman, Carole. The Sexual Contract. Wiley, 1988.

Picq, Manuela Lavinas, and Marcus Thiel. Sexualities in World Politics: How LGBTQ Claims Shape International Relations. Taylor \& Francis, 2015.

Powell, Derek. "The Role of Constitution Making and Institution Building in Furthering Peace, Justice and Development: South Africa's Democratic Transition." The International Journal of Transitional Justice, vol. 4, no. 2, July 2010, pp. 230-50.

Puar, Jasbir. "Rethinking Homonationalism." International Journal of Middle East Studies, vol. 45 , no. 2, 2013, pp. 336-39. 
Radford, Katy. "Narrative-Making and Recording Trauma: Reflections from Northern Ireland." Civil War and Narrative: Testimony, Historiography, Memory, edited by Karine Deslandes, Fabrice Mourlon, and Bruno Tribout, Palgrave Macmillan, 2017, pp. 91-105.

Reuters. “'Homosexuellen-Paragraph' Fällt Heute Weg." Frankfurter Allgemeine Zeitung, Frankfurter Allgemeine Zeitung GmbH, 19 June 1994, p. 1 Politics.

Rey, Michel. "Parisian Homosexuals Create a Lifestyle, 1700-1750." Eighteenth-Century Life, vol. 9, no. 3, 1985, pp. 179-91.

Rocke, Michael. Forbidden Friendships: Homosexuality and Male Culture in Renaissance Florence. Oxford UP, 1996.

Roediger, Henry L., III, Yadin Dudai, and Susan M. Fitzpatrick. Science of Memory: Concepts. Oxford UP, 2007.

Röll, W. "Homosexual Inmates in the Buchenwald Concentration Camp." Journal of Homosexuality, vol. 31, no. 4, 1996, pp. 1-28.

Rooney, Eilish, and Fionnuala Ní Aoláin. "Transitional Justice from the Margins: Intersections of Identities, Power and Human Rights." The International Journal of Transitional Justice, vol. 12, no.1, 2018, pp. 1-8. DOI:10.1093/ijtj/ijyoo1.

Roper, John Herbert. The Gemeinschaft Der Eigenen and the Cultural Politics of Homoeroticism in Germany, 1896-1933. PhD Dissertation. University of Pennsylvania, 24 Nov. 2014, http://repository.upenn.edu/dissertations/AAI3635545/. Accessed 13 Feb. 2019.

Rothberg, Michael. Multidirectional Memory: Remembering the Holocaust in the Age of Decolonization (Cultural Memory in the Present). First edition, Stanford UP, 2009.

Rubio-Marín, Ruth, and Pablo de Greiff. "Women and Reparations." The International Journal of Transitional Justice, vol. 1, no. 3, Dec. 2007, pp. 318-37.

Schulman, Sarah. "Israel and 'Pinkwashing." The New York Times, 22 Nov. 2011, https:// www.nytimes.com/2011/11/23/opinion/pinkwashing-and-israels-use-of-gays-as-amessaging-tool.html. Accessed 13 Feb. 2019.

Schult, Peter. Besuche in Sackgassen: Aufzeichnungen Eines Homosexuellen Anarchisten. Auflage 1, Foerster, 1982.

Smale, Allison. "Teaching the Holocaust to Muslim Germans, or Not." The New York Times, 17 June 2015, https://www.nytimes.com/2015/o6/18/world/europe/teaching-theholocaust-to-muslim-germans-or-not.html. Accessed 13 Feb. 2019.

Spiegelman, Art. Maus: A Survivor's Tale. Pantheon Books, 1986.

--. Maus II: A Survivor's Tale: And Here My Troubles Began. Gph Rep edition, Pantheon, 1992.

Steakley, James D. The Homosexual Emancipation Movement in Germany. Arno Press, 1975.

Stojka, Ceija. Wir Leben Im Verborgenen. Erinnerungen Einer Rom-Zigeunerin. Picus Verlag, 1 January 1988.

Stone, Dan. The Historiography of the Holocaust. First edition, Palgrave Macmillan, 2006.

Stroh, Von Kassian. "Maßnahmenkatalog Gegen HIV - Als Die CSU in Den Krieg Gegen Aids Zog.” Süddeutsche Zeitung, 24 Feb. 2012, https://www.sueddeutsche.de/bayern/ 
massnahmenkatalog-gegen-hiv-als-die-csu-in-den-krieg-gegen-aids-zog-1.1292107. Accessed 13 Feb. 2019.

Tamagne, Florence. A History of Homosexuality in Europe, Vol. I \& II: Berlin, London, Paris; 1919-1939. Algora Publishing, 2006.

Vijeyarasa, Ramona. "Women at the Margins of International Law: Reconceptualizing Dominant Discourses on Gender and Transitional Justice." The International Journal of Transitional Justice, vol. 7, no. 2, 2013, pp. 358-69.

Weinthal, Benjamin. "Last Gay Jewish Holocaust Survivor Dies." The Jerusalem Post, 25 June 2012, http://www.jpost.com/Jewish-World/Jewish-News/Last-gay-JewishHolocaust-survivor-dies. Accessed 13 Feb. 2019.

Weiss, M. L., and M. J. Bosia. Global Homophobia: States, Movements, and the Politics of Oppression. U of Illinois P, 2013.

Welle, Deutsche. "Holocaust Academic Pans Monument to Nazis' Gay Victims." Deutsche Welle, 29 May 2008, http://www.dw.com/en/holocaust-academic-pans-monument-tonazis-gay-victims/a-3368183. Accessed 13 Feb. 2019.

Wiesel, Elie. Night. Farrar, Straus and Giroux, 2012.

Wiesenthal, Simon. The Murderers among Us: The Simon Wiesenthal Memoirs. 1st edition, McGraw-Hill, 1967.

Wilke, Christiane. "Remembering Complexity? Memorials for Nazi Victims in Berlin." International Journal of Transitional Justice, vol. 7, no. 1, 2013, pp. 136-56. 